\title{
RESCUING CATTLEYA GRANULOSA LINDLEY IN THE WILD
}

\author{
Clementino Camara-Neto ${ }^{1,3}$, Iuna Chaves-Camara ${ }^{1}$, \\ Severino Carvalho de Medeiros ${ }^{1} \&$ Maria do Rosario de Almeida Braga ${ }^{2}$ \\ ${ }^{1}$ Sociedade Orquidófila do Rio Grande do Norte, Natal, RN, Brasil \\ ?²OrquidaRio Orquidófilos Associados, Rua Visconde de Inhaúma, 134/428, Rio de Janeiro, \\ RJ, 20091-000, Brasil \\ ${ }^{3}$ Author for correspondence: orquidario@orquidario.org
}

\begin{abstract}
KEY WoRDS: Cattleya granulosa, Brazil, habitat destruction, re-introduction, plant morphology
\end{abstract}
\section{Introduction}

The Orchid Society of Rio Grande do Norte State, Brazil, through its Group of Experimental Interactive Research (SORN/GEPI), has been studying the occurrence of Cattleya granulosa Lindley, 1842 , specifically in the coastal sand plain and dune vegetation ("restinga") and in remaining patches of Atlantic Rainforest in the state. C. granulosa is threatened largely by urban development and, at a smaller scale, by plant collectors (Ferreira, 1992). It is, in theory, a biological indicator of reasonable importance for the evaluation of the ecological equilibrium in the sand plain vegetation dominated by Eugeniacea spp (Myrtaceae). C. granulosa is sensitive to urban development, climatic variations and to the attack of insects and mammals and its morphology reflects any of these aggressions. Mapping and characterizing the different populations of C. granulosa will provide additional information necessary for the continuation of existing programs of SORN/GEPI: (a) Project "Adopt an Orchid" (Cattleya granulosa), with the goal of stopping orchid collection in the wild and making cultivated seedlings available, and (b) Program "The Cattleya granulosa universe" directed at primary school and high school students. The latter program includes guided field trips with instruction about the sand dune ecosystem, distribution of C. granulosa, and the importance of its conservation, considering the interdependence between orchids and the environmental physical, chemical and biological characteristics. The main goal of this project is to characterize the habitats where this species grows, in order to make models for their introduction in other areas and to be able to protect them in areas of ecological stress.

\section{Methods}

Areas for study will be delimitated and plotted on a map (DHN number 23400) using GPS data. Soil samples will be collected in different $C$. granulosa habitats and sent for macro and micro nutrient analysis. Plant species associated with $C$. granulosa will be identified and, whenever necessary, they will be collected and dried, to make herbarium specimens. Five specimens of Cattleya granulosa, at each study site, will be marked and measurements will be made (number of pseudobulbs, estimated age, biometric parameters). Some will be dried to make herbarium specimens. Capsules will be collected from different sites, for sowing and germination of $C$. granulosa, using asymbiotic orchid culture techniques. Two to three-year-old seedlings will be introduced to the areas from where the seeds have been collected or in protected areas in the neighborhood.

\section{Previous Results}

All populations of Cattleya granulosa studied occurred on sand dunes covered by low vegetation, at a distance of 0.5 to $3 \mathrm{~km}$ from the beach (Fig. 1). All plants were found entangled with scrubs and bromeliads and most of them were growing on branches close to the sand (Fig. 2-4). Populations were mapped for $120 \mathrm{~km}$, from lat. $06^{\circ} 10^{\prime} 30^{\prime}$ 'S, long. $35^{\circ} 50^{\prime} 30^{\prime \prime} \mathrm{W}$ to lat. $05^{\circ} 08^{\prime} 50^{\prime}, \mathrm{S}$, long. $35^{\circ} 34^{\prime} 19^{\prime}$ ' W. 


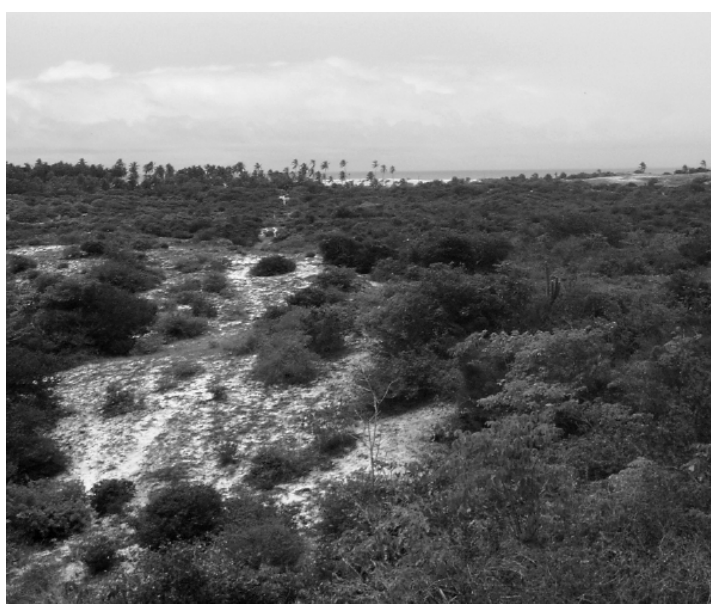

FIGURE 1. Sand dune low vegetation habitat near Natal, RN, Brasil.

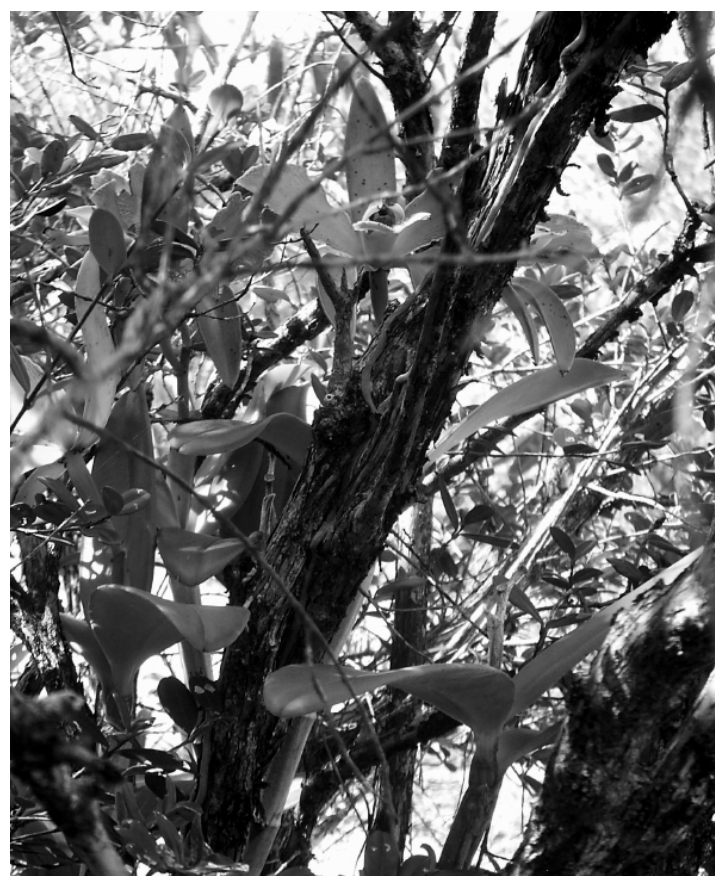

FIGURE 3. Cattleya granulosa epiphytic on Eugenia sp (Myrtaceae).

Analysis of measurements made up to now, on 75 plants and a total of 300 pseudobulbs (the four last ones of each plant), showed a continuum in length variation from $4 \mathrm{~cm}$ to $97 \mathrm{~cm}$, with up to $73 \%$ between $21-50 \mathrm{~cm}$. Length $(5$ to $30 \mathrm{~cm}$ ) and width $(1.5$ to $11 \mathrm{~cm})$ of the larger leaves, as well as diameter of flowers (3 to $15 \mathrm{~cm}$ ) also varied a lot among the sampled plants. Number of flowers per spike

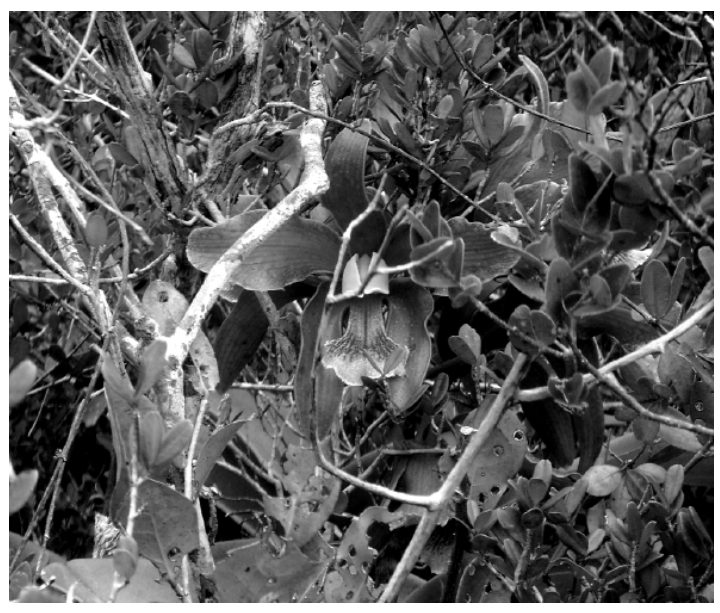

FIGURE 2. Cattleya granulosa growing among shrubs.

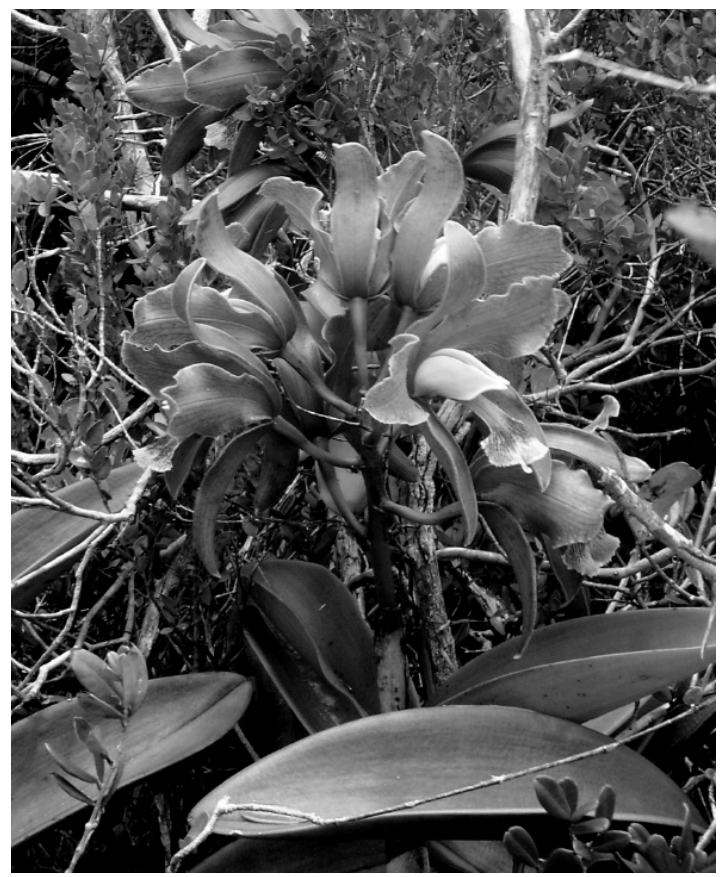

FIGURE 4. Cattleya granulosa flowers appearing above the height of the vegetation patch.

was between 1 and 18, although most of the plants analyzed had from one to five flowers per spike. Very few fruits were found in the field. Up to now no clear morphological distinction between the different populations has been found (Câmara Neto et al., 2005)

During the raining season (March to June) adult plants from different populations were reintroduced 


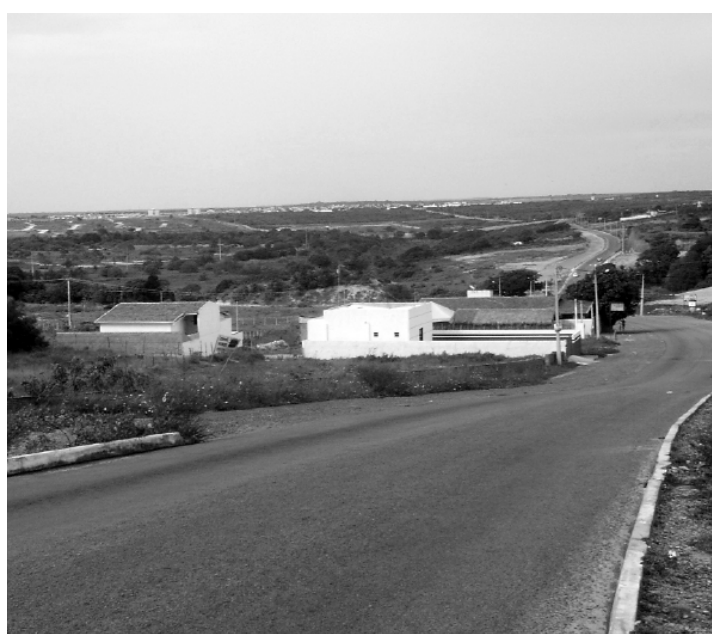

FIGURE 5. Urban expansion in the "restinga" area.

in a private ecological reserve in order to test their reliance to the process. One year after being transplanted all of them looked healthy and flowered. Rescue actions in areas to be used for urban developments and introduction of those plants in private land (ecological reserves or not) is continuing, although with many difficulties.

A few years ago one hundred seedlings of Cattleya granulosa were distributed among an interested public that registered themselves, as part of the sub-project "Adopt an orchid". On the occasion, 600 people applied to be entitled to grow one seedling of what people from Rio Grande do Norte State know as "the orchid". In 2007 the first group of people who were given seedlings will be visited for the following up of the project. Thousands of seedlings of different varieties of $C$. granulosa are growing in the lab.

\section{Discussion}

The expansion of urban boundaries and the construction of infrastructure for tourism in recent years (Fig. 5-6) have been added to traditionally destructive uses of the environment, making the "restinga" one of the most threatened ecosystems in Brazil. The "restinga" is considered part of the Atlantic Rainforest dominium and only 5-7\% of this biome is still left. In the last two decades especially in the NE states of Brazil, there has been

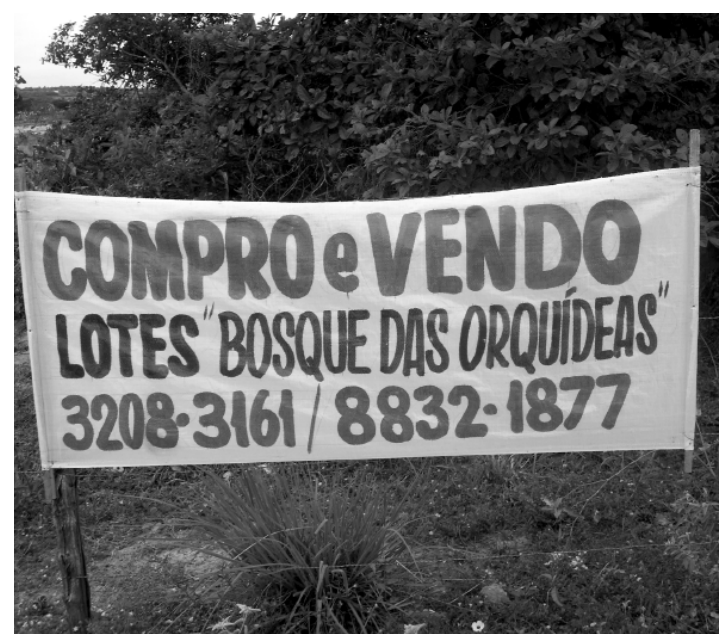

FiguRE 6. "Orchid Woods" urban development in area to be deforested.

a boom of settlement of this almost flat plain near the coast, and the native vegetation of the "restinga", the only habitat of Cattleya granulosa, is disappearing quickly. Sometimes it is only a matter of a few days, or even few hours, for large areas of native vegetation to be razed to give way to legal "loteamentos" (subdivisions). This has been happening faster than the local orchid societies are able to act and rescue the plants.

On the other hand, Cattleya granulosa, which has flowers with a large color and pattern variation, is still very susceptible to orchid collectors. Most orchid collections in Rio Grande do Norte State have many varieties of the species and, as it is a species rarely available in commercial nurseries, collectors are often looking for another exclusive plant from the remaining patches of "restinga".

The SORN/GEPI group has now chosen a second private property, located in the natural environment of Cattleya granulosa, to reintroduce plants rescued from the surrounded area. As public protected areas in the state are rare and not well looked after, our goal is to create a network of private areas committed to conservation and that will maintain the genetic diversity of the species.

Acknowledgments. To all the members of the "Sociedade Orquidófila do Rio Grande do Norte" who have helped with the field work and educational project. 
LiteratuRE Cited

Câmara-Neto, C., I. Chaves-Câmara\& W. Prado-Martins. 2005. Contribuição ao Conhecimento da Ocorrência da Cattleya granulosa Lindley, 1842, na Vegetação de
Restinga do Litoral do Rio Grande do Norte. Orquidário, 19 (2): 48-55.

Ferreira, A. 1992. Subsídios ao Projeto Granulosae. Recife, SOPE. 42pp.

Clementino Câmara-Neto is a chemist. For ten years he has been interested in orchids and especially in the conservation of Cattleya granulosa. He was one of the founders of the Group of Experimental Interactive Research and has participated on many projects in conservation of the species and its habitat, its reproduction and environmental education. He has produced a video and published several articles on the subject. His other area of research in orchids is with seaweed fertilizers.

Iuná Chaves-Câmara is a geographer and worked as a school teacher. Together with her husband Clementino, she was one of the founders of the Group of Experimental Interactive Research and has participated on many projects on conservation of the species and its habitat, its reproduction and environmental education.

Severino Carvalho de Medeiros is an accountant and a life-long orchid lover. He has been the president of the Orchid Society of Rio Grande do Norte State for many years and has always been interested in and evolved with the propagation and conservation of Cattleya granulosa.

Maria do Rosário de Almeida Braga has a Masters degree in Botany. She started to work with orchids in 1994 at a commercial orchid nursery, in Petrópolis, RJ. Until 2004 she ran the business although her main interest has always been Conservation. The nursery is now closed but Rosário maintains the laboratory working and reproducing Brazilian species of orchids. She is the present president of "OrquidaRio Orquidófilos Associados" (the Orchid Society of Rio de Janeiro) and is a director of Orchid Conservation Alliance. 